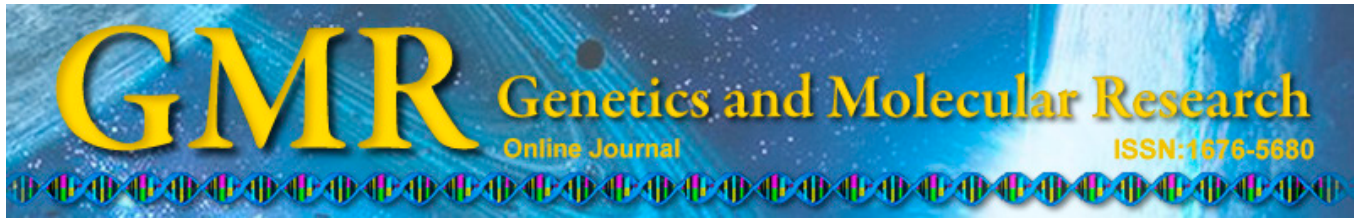

\title{
Analysis of genetic diversity of the heat shock protein 70 gene on the basis of abundant sequence polymorphisms in chicken breeds
}

\author{
J.K. Gan ${ }^{1,2,3 *}$, L.Y. Jiang ${ }^{3 *}$, L.N. Kong ${ }^{1,3}$, X.Q. Zhang ${ }^{1,3}$ and Q.B. Luo ${ }^{1,3}$ \\ ${ }^{1}$ Department of Animal Genetics, Breeding and Reproduction, \\ College of Animal Science, South China Agricultural University, \\ Guangzhou, China \\ ${ }^{2}$ Xinguang Agriculture \& Animal Husbandry Co., Ltd., Gaoming District, \\ Foshan, China \\ ${ }^{3}$ Key Lab of Chicken Genetics, Breeding and Reproduction, \\ Ministry of Agriculture, South China Agricultural University, Guangzhou, China \\ *These authors contributed equally to this study. \\ Corresponding author: Q.B. Luo \\ E-mail: qbluo@scau.edu.cn
}

Genet. Mol. Res. 14 (1): 1538-1545 (2015)

Received November 26, 2013

Accepted April 13, 2014

Published March 6, 2015

DOI http://dx.doi.org/10.4238/2015.March.6.1

\begin{abstract}
This study was designed to detect the sequence variation of the chicken heat shock protein 70 (HSP70) gene. A total of 102 individuals from 8 native Chinese breeds together with Dwarf White Chicken and Red Junglefowl were used to detect sequence variations. The coding regions of the chicken HSP70 gene from 102 individuals were cloned and sequenced. Thirty-six variations were identified, which included 34 single nucleotide polymorphisms and 2 indel mutations. Fifty-seven haplotypes were observed, of which, 43 were breed-specific and 14 were shared. There were 7 Red Junglefowl-specific haplotypes, while Haidong and Silkie only had 2 specific haplotypes. Eleven and 3 haplotypes were shared between and within species, respectively. The variation in nucleotide diversity $(\mathrm{Pi})$ and average number of nucleotide
\end{abstract}


differences $(\mathrm{K})$ among species were consistent. The total Pi of HSP70 was 0.0016 , and the total $\mathrm{K}$ was 4.1998 . The Pi value of Red Junglefowl was the highest (0.0018) and $\mathrm{K}$ was 4.8000 , while the Pi of Silkie was the lowest (0.0010) and $\mathrm{K}$ was 2.5000. These results demonstrated that variation in chicken $H S P 70$ was abundant between and within species.

Key words: Chicken; HSP70; Single nucleotide polymorphism; Haplotype

\section{INTRODUCTION}

Heredity and variation are the cause of the species diversity, and heritable variation provides the raw material for biological evolution (Janecka et al., 2012). Remarkable differences in sequence evolution have been noted across lineages of mammals and other organisms (Welch and Bromham, 2005). Sequence mutations and the subsequent fixation of these variations yield the initial heritable variation that leads to adaptation and subsequently speciation (Bromham, 2009). Heat shock protein 70 (HSP70) is a member of the heat shock protein family (Kregel, 2002). As a molecular chaperone, it plays a critical role in the regulation of the heat shock response and the acquisition of thermotolerance (Mayer and Bukau, 2005; Guo et al., 2012). Local chicken varieties in China are diverse and have different levels of thermal resistance. We hypothesized that this could possibly be related to variations in the HSP70 gene sequence. Furthermore, there could be differences in the $H S P 70$ sequence evolution among these local species and their ancestor Red Junglefowl. The HSP70 gene families in Stratiomys singularior and Oxycera pardalina evolved quite differently from one another (Garbuz et al., 2011). In this study, we investigated the sequence variation in the HSP70 gene in 10 populations, including 8 native Chinese chicken populations, Dwarf White chicken, and Red Junglefowl. Single nucleotide polymorphisms (SNPs) of the HSP70 gene were detected by sequencing, haplotype and genetic diversity analyses of the $H S P 70$ gene were performed, and genetic differentiation of the $H S P 70$ gene was analyzed in the 10 chicken populations.

\section{MATERIAL AND METHODS}

\section{Samples and DNA extraction}

Blood samples of 102 chickens from 8 native Chinese populations, Dwarf White chicken (Xinguang Agriculture and Animal Husbandry Co., Ltd., China), and Red Junglefowl were collected. Information about the blood samples is listed in Table S1. Genomic DNA of the 102 individuals was extracted by a standard phenol-chloroform method.

\section{Polymerase chain reaction (PCR) amplification}

The following primer pair was designed based on the chicken HSP70 gene (GenBank accession No. J02579): forward, 5'-CGATCTGGCTGCAATCTACG-3', and reverse, 5'-ATTTCCAGAAGCTGCACTTGG-3'. The amplification product was $2591 \mathrm{bp}$. The PCR mixture consisted of $1 \mu \mathrm{L}$ chicken DNA, $0.25 \mu \mathrm{L} 10 \mu \mathrm{M}$ primers, $3.2 \mu \mathrm{L}$ dNTP mixture, 0.2 $\mu \mathrm{L}$ LA Taq DNA polymerase (TaKaRa, Japan), $2.0 \mu \mathrm{L}$ 10X LA PCR Buffer II, and $\mathrm{ddH}_{2} \mathrm{O}$ (to 
a final volume of $20 \mu \mathrm{L}$ ). After denaturation at $94^{\circ} \mathrm{C}$ for $3 \mathrm{~min}$, samples were subjected to 32 cycles of $94^{\circ} \mathrm{C}$ for $30 \mathrm{~s}, 62^{\circ} \mathrm{C}$ for $30 \mathrm{~s}$, and $72^{\circ} \mathrm{C}$ for $45 \mathrm{~s}$, after which a final elongation step of $72^{\circ} \mathrm{C}$ for 6 min was included. PCR products were analyzed by electrophoresis on a $1.2 \%$ agarose gel containing ethidium bromide.

\section{Cloning and sequencing}

PCR products were purified using the E.Z.N.A. ${ }^{\mathrm{TM}}$ Gel Extraction Kit (Omega, USA). The purified products were ligated into the pGEM-T vector and cloned into Escherichia coli DH5 $\alpha$ cells according to the standard protocol. Positive samples were sequenced by BGI Company (China).

\section{Statistical analysis}

Sequence alignment and polymorphism detection were performed using DNASTAR. Haplotypes were determined by Clustal X 1.81 and MEGA 4.0 (Tamura et al., 2007). Haplotype diversity, nucleotide diversity, and neutral tests were determined using DnaSP4.9 (Rozas et al., 2003). Analysis of molecular variance (AMOVA) of the HSP70 gene was carried out using Areliquin3.11, and genetic variation was calculated by the fixation index.

\section{RESULTS}

\section{Polymorphisms of the chicken HSP70 gene}

A product of 2591 bp was obtained by PCR amplification, which included a 322-bp 5'flanking region, a 1905-bp open reading frame, and a 364-bp 3'-noncoding region. Sequence alignment revealed 34 SNPs and 2 indel mutations (Table 1), among which 6 variations were located in the 5 '-flanking region, 24 were in the coding region, and 6 were in the 3 '-noncoding region. Thirty SNPs were transitions and the other 4 were transversions. Of the 24 SNPs in the coding region, 16 were in the ATP enzyme active region, 7 were in the polypeptide combining region, and 1 was in C-terminal region; additionally, 7 SNPs caused amino acid changes Table S2.

Table 1. Distribution of single nucleotide polymorphism locations in the chicken HSP70 gene.

\begin{tabular}{|c|c|c|c|c|c|c|c|}
\hline Number & Position & Variation type & Region & Number & Position & Variation type & Region \\
\hline 1 & C. $298 \mathrm{~A}>\mathrm{G}$ & Transition & 5'-flanking region & 19 & C. $629 \mathrm{~T}>\mathrm{C}$ & Transition & Coding region \\
\hline 2 & C. $237 \mathrm{~T}>\mathrm{A}$ & Transversion & 5 '-flanking region & 20 & C. $812 \mathrm{~A}>\mathrm{G}$ & Transition & Coding region \\
\hline 3 & C. $72 \mathrm{~A}>\mathrm{G}$ & Transition & 5 '-flanking region & 21 & C. $909 \mathrm{C}>\mathrm{A}$ & Transversion & Coding region \\
\hline 4 & C. $69 A>G$ & Transition & 5'-flanking region & 22 & C. $1044 \mathrm{G}>\mathrm{A}$ & Transition & Coding region \\
\hline 5 & C. $34 \mathrm{C}>\mathrm{T}$ & Transition & 5'-flanking region & 23 & C. $1431 \mathrm{C}>\mathrm{A}$ & Transversion & Coding region \\
\hline 6 & C. $10 \mathrm{~A}>\mathrm{G}$ & Transition & 5'-flanking region & 24 & C. $1437 \mathrm{C}>\mathrm{T}$ & Transition & Coding region \\
\hline 7 & C. $57 \mathrm{G}>\mathrm{A}$ & Transition & Coding region & 25 & C. $1476 \mathrm{~T}>\mathrm{C}$ & Transition & Coding region \\
\hline 8 & C. $106 \mathrm{~A}>\mathrm{G}$ & Transition & Coding region & 26 & C. $1500 \mathrm{G}>\mathrm{A}$ & Transition & Coding region \\
\hline 9 & C. $138 \mathrm{C}>\mathrm{T}$ & Transition & Coding region & 27 & C. $1503 \mathrm{G}>\mathrm{A}$ & Transition & Coding region \\
\hline 10 & C. $258 \mathrm{~A}>\mathrm{G}$ & Transition & Coding region & 28 & C. $1512 \mathrm{~A}>\mathrm{G}$ & Transition & Coding region \\
\hline 11 & C. $276 \mathrm{C}>\mathrm{G}$ & Transversion & Coding region & 29 & C. $1587 \mathrm{~A}>\mathrm{G}$ & Transition & Coding region \\
\hline 12 & C. $289 A>G$ & Transition & Coding region & 30 & C. $1639 \mathrm{~T}>\mathrm{C}$ & Transition & Coding region \\
\hline 13 & C. $291 \mathrm{C}>\mathrm{T}$ & Transition & Coding region & 31 & C. $1908 \mathrm{~A}>\mathrm{G}$ & Transition & 3'-noncoding region \\
\hline 14 & C. $426 \mathrm{~T}>\mathrm{C}$ & Transition & Coding region & 32 & C. $1970 I>D$ & $\mathrm{~T}$ indel & 3 '-noncoding region \\
\hline 15 & C. $456 \mathrm{C}>\mathrm{T}$ & Transition & Coding region & 33 & C. $2067 \mathrm{~A}>\mathrm{G}$ & Transition & 3'-noncoding region \\
\hline 16 & C. $507 \mathrm{C}>\mathrm{T}$ & Transition & Coding region & 34 & C. $2117 \mathrm{~A}>\mathrm{G}$ & Transition & 3'-noncoding region \\
\hline 17 & C. $550 \mathrm{~T}>\mathrm{C}$ & Transition & Coding region & 35 & C. $2133 \mathrm{~A}>\mathrm{G}$ & Transition & 3 '-noncoding region \\
\hline 18 & C. $555 \mathrm{C}>\mathrm{T}$ & Transition & Coding region & 36 & C. $2218 \mathrm{I}>\mathrm{D}$ & A indel & 3'-noncoding region \\
\hline
\end{tabular}




\section{Haplotype analysis}

Fifty-seven haplotypes were found (Table 2).

\section{Table 2. HSP70 haplotypes in 10 chicken breeds.}

\begin{tabular}{|c|c|c|c|c|}
\hline Haplotype number & $\begin{array}{r}22233445 \\
2855817257 \\
5614928799\end{array}$ & $\begin{array}{r}1 \\
5667788891 \\
9114727753 \\
7027781603\end{array}$ & $\begin{array}{l}1111111111 \\
2377788899 \\
3655922306 \\
0528714380\end{array}$ & $\begin{array}{l}2222 \\
2344 \\
2835 \\
9884\end{array}$ \\
\hline H1 & ATAACAGACG & САСТССТСТА & CGCCCGGAAT & AAAA \\
\hline $\mathrm{H} 2$ & $\ldots$. G... & $\ldots \ldots \ldots$ & $\ldots \ldots \ldots$ & $\ldots$ \\
\hline H3 & $\ldots \ldots \ldots$ & $\ldots \ldots \ldots$ & $\ldots \ldots \ldots$ & G... \\
\hline $\mathrm{H} 4$ & $\ldots \ldots \ldots$ & $\ldots \ldots \ldots$ & $\ldots \ldots \ldots$ & . GG. \\
\hline H5 & $\ldots \ldots$ A. & G.T.... & $\ldots \ldots \ldots$ & $\ldots$ \\
\hline H6 & $\ldots G \ldots \ldots$ & $\ldots \ldots \ldots$ & $\ldots \ldots \ldots$ & $\ldots$ \\
\hline $\mathrm{H} 7$ & $\ldots \ldots \ldots$ & $\ldots \ldots \ldots$ & А... $\ldots$. & $\ldots$ \\
\hline H8 & $\ldots \ldots \ldots$ & $\ldots \ldots c$ & А...T.... & $\ldots$ \\
\hline H9 & $\ldots \ldots \ldots$ & $\ldots \ldots \ldots$ & A... .A... & $\ldots$ \\
\hline $\mathrm{H} 10$ & $\ldots \ldots \ldots$ & $\ldots \ldots \ldots$ & A........ & $\ldots$ \\
\hline H11 & $\ldots G \ldots \ldots$ & $\ldots \ldots \ldots$ & $\ldots$. . . & $\ldots$ \\
\hline $\mathrm{H} 12$ & $\ldots \ldots \ldots$ & $\ldots \ldots \ldots$ & $\ldots$. . . & $\ldots$ \\
\hline H13 & $\ldots \ldots \ldots$ & $\ldots \ldots \ldots$ & .А. . . . & $\ldots$ \\
\hline $\mathrm{H} 14$ & $\ldots \ldots \ldots$ & $\ldots \ldots \ldots$ & .А.ТТ... & $\ldots$ \\
\hline H15 & $\ldots$...G. & $\ldots \mathrm{T} \ldots \mathrm{G}$ & . .TA... & $\ldots$ \\
\hline H16 & $\ldots \ldots \ldots$ & $\ldots \ldots G$ & ...TA... & $\ldots$ \\
\hline H17 & $\ldots \ldots \ldots$ & $\ldots$....... & ...TA... & $\ldots$ \\
\hline H18 & $\ldots G \ldots A$ & $\ldots \ldots \ldots$ & A... .... & $\ldots$ \\
\hline H19 & $\ldots G \ldots A$ & $\ldots \ldots \ldots$ & A........ & $\ldots$ \\
\hline $\mathrm{H} 20$ & $\ldots G \ldots A$ & $\ldots \ldots \ldots$ & $\ldots \ldots \ldots$ & $\ldots$ \\
\hline $\mathrm{H} 21$ & $\ldots G \ldots A$ & $\ldots \ldots \ldots$ & $\ldots \ldots G$. & $\ldots$ \\
\hline $\mathrm{H} 22$ & $\ldots G \ldots A$ & $\ldots$. . . & .A. . . . & $\ldots$ \\
\hline $\mathrm{H} 23$ & $\ldots G \ldots A$ & $\ldots \ldots \ldots$ & $\ldots$. & $\ldots$ \\
\hline $\mathrm{H} 24$ & $\ldots G \ldots$ A & $\ldots \ldots \ldots$ & ...TA... & $\ldots$ \\
\hline $\mathrm{H} 25$ & $G \ldots G \ldots A$ & $\ldots \ldots \ldots$ & . .TA... & $\ldots$ \\
\hline $\mathrm{H} 26$ & $\ldots G \ldots A$ & $\ldots \ldots$ & ... & G. \\
\hline $\mathrm{H} 27$ & $\ldots G \ldots . A$ & $\ldots \ldots$.... & .A.TA... & $\ldots$ \\
\hline $\mathrm{H} 28$ & $\ldots G \ldots$. A & $\ldots \ldots \ldots$ & $\ldots$. . . & $\ldots$ \\
\hline $\mathrm{H} 29$ & ..G..G.A & $\ldots \ldots \ldots$ & ....... & $\ldots$ \\
\hline $\mathrm{H} 30$ & $\ldots \ldots \ldots$ & $G \ldots \ldots$ & .A.TT.... & $\ldots$ \\
\hline $\mathrm{H} 31$ & $\ldots$....A & $G \ldots \ldots \ldots$ & .A.TT.... & G... \\
\hline H32 & $\ldots \ldots \ldots$ & G....T. & .А.ТT.... & $\ldots$ \\
\hline H33 & $\ldots \ldots \ldots$ & G....T. & .A.TT ...C & $\ldots$ \\
\hline H34 & $\ldots \ldots \ldots$ & GG..... & .A.TT.... & $\ldots$ \\
\hline H35 & $\ldots \ldots A$ & G...T. & .A. . . & $\ldots$ \\
\hline H36 & $\ldots \ldots \ldots$ & G....T. & . & $\ldots$ \\
\hline $\mathrm{H} 37$ & $\ldots \ldots \ldots$ & $G \ldots \ldots$ &.$A \ldots \ldots$ & $\ldots$ \\
\hline H38 & $\ldots \ldots \ldots$ & G...C... & .A. . . . & $\ldots$ \\
\hline H39 & $\mathrm{G} \ldots \ldots \mathrm{A}$ & G......... & A....... & $\ldots$ \\
\hline $\mathrm{H} 40$ & $\ldots \ldots \ldots$ & $G \ldots \ldots$ & $\ldots \ldots \ldots$ & $\ldots$ \\
\hline H41 & $\ldots \ldots A$ & G..CT.... & $\ldots \ldots \ldots$ & $\ldots$ \\
\hline $\mathrm{H} 42$ & $\ldots G \ldots \ldots A$ & G..T... & $\ldots \ldots \ldots$ & $\ldots$ \\
\hline $\mathrm{H} 43$ & $\ldots \ldots \ldots$ & $G \ldots \ldots$ & $\ldots \ldots$. G & $\ldots$ \\
\hline H44 & $\ldots \ldots \ldots$ & $G \ldots \ldots \ldots$ & $\ldots A \ldots \ldots$ & $\ldots$ \\
\hline H45 & $\ldots \ldots \ldots$ & GG $\ldots \ldots$ & $\ldots A \ldots \ldots$ & $\ldots$ \\
\hline H46 & $\ldots \mathrm{T} \ldots \mathrm{TA}$ & $G \ldots \ldots$ & .А. T... & $\ldots$ \\
\hline H47 & $\ldots \mathrm{T} \ldots \mathrm{TA}$ & $G \ldots \ldots$ & .A. . TA... & $\ldots$ \\
\hline H48 & $\ldots \mathrm{T} \ldots \mathrm{TA}$ & $G \ldots \ldots$ & $\ldots$. . . & $\ldots$ \\
\hline H49 & $\ldots \mathrm{T} \ldots \mathrm{TA}$ & $G \ldots \ldots$ & $\ldots$ A..A. & $\ldots$ \\
\hline $\mathrm{H} 50$ &.$A \ldots \ldots$ A & $G \ldots \ldots$ & $\ldots$. . . . & $\ldots G$ \\
\hline H51 & $\ldots \ldots A$ & G......... & ... ... & $\ldots G$ \\
\hline H52 & $\ldots \ldots \ldots$ & $G \ldots \ldots$ & $\ldots$. . . . & . GG \\
\hline H53 & $\ldots \ldots \ldots$ & $G \ldots \ldots$ & A... $\ldots$. & $\ldots G$ \\
\hline H54 & $\ldots \ldots \ldots$ & G........ & ...... & $\ldots$ \\
\hline H55 & $\ldots \ldots \ldots$ & $\ldots \ldots \ldots$ & . . . TA... & $\ldots$ \\
\hline H56 & $\ldots \ldots \ldots$ & $\ldots \ldots \ldots$ & ...TA.G. & $\ldots$ \\
\hline H57 & $\ldots \ldots \ldots$ & $G \ldots \ldots$ & $\ldots$. . . . & $\ldots$ \\
\hline
\end{tabular}

$\mathrm{H}=$ haplotype. The dots represent bases that are identical to the reference sequence $(\mathrm{H} 1)$. 
Of these, 43 were breed-specific (Table 3 ) and 14 were shared (Table 4). The H1, H5, H7, H13, H20, H23, H28, H30, H32, H37, and H40 haplotypes were shared among breeds; the H44, H48, and H50 haplotypes were shared within breeds (Table 3). The H7, H13, and H23 haplotypes had the highest frequency, while the H9 and H54 haplotypes had the lowest frequency. However, H7 had the highest frequency in the Taibai breed, H13 had the highest frequency in the Haidong breed, and H23 had the highest frequency in the Silkie breed. The Red Junglefowl had 7 breed-specific haplotypes, which was the most of any breed, and the Big Bone and Silkie breeds had 2 breed-specific haplotypes, which was the least of the breeds.

Table 3. HSP70 haplotypes shared within and between 10 chicken breeds.

\begin{tabular}{|c|c|c|c|c|c|c|c|c|c|c|c|}
\hline \multirow{2}{*}{ Shared haplotypes } & \multirow{2}{*}{ Number } & \multicolumn{10}{|c|}{ Breed } \\
\hline & & DG & $\mathrm{HD}$ & $\mathrm{TB}$ & SY & ZJ & $\mathrm{XH}$ & QY & LS & DW & RJF \\
\hline H1 & 6 & 1 & & & & & & 1 & 2 & 2 & \\
\hline H5 & 2 & 1 & & 1 & & & & & & & \\
\hline H7 & 8 & & & 3 & 1 & & & 1 & 1 & 2 & \\
\hline H13 & 8 & & 5 & 1 & & 1 & & 1 & & & \\
\hline $\mathrm{H} 20$ & 2 & 1 & & & & & 1 & & & & \\
\hline $\mathrm{H} 23$ & 8 & & & & 5 & & 1 & & 1 & & 1 \\
\hline $\mathrm{H} 28$ & 4 & 3 & & 1 & & & & & & & \\
\hline $\mathrm{H} 30$ & 3 & 1 & & & 1 & & & & 1 & & \\
\hline H32 & 2 & & 1 & & & 1 & & & & & \\
\hline H37 & 6 & 1 & 3 & & & & 1 & & & 1 & \\
\hline $\mathrm{H} 40$ & 4 & & & 1 & & 2 & & & & & 1 \\
\hline H44 & 2 & & & & & 2 & & & & & \\
\hline $\mathrm{H} 48$ & 2 & & & & & & & & & & 2 \\
\hline H50 & 2 & & & & & & & & 2 & & \\
\hline
\end{tabular}

Big Bone (DG), Haidong (HD), Taibai (TB), Silkie (SY), Tibet (ZJ), Xinghua (XH), Qingyuan (QY), Lingshan (LS), Dwarf White (DW), and Red Junglefowl (RJF).

Table 4. Breed-specific HSP70 haplotypes in 10 chicken breeds.

\begin{tabular}{llc}
\hline Breed & Unique haplotypes & Number \\
\hline DG & $\mathrm{H} 2, \mathrm{H} 57$ & 2 \\
HD & $\mathrm{H} 4, \mathrm{H} 31, \mathrm{H} 36$ & 3 \\
TB & $\mathrm{H} 6, \mathrm{H} 8, \mathrm{H} 29, \mathrm{H} 42, \mathrm{H} 54$ & 5 \\
SY & $\mathrm{H} 19, \mathrm{H} 55, \mathrm{H} 11, \mathrm{H} 41, \mathrm{H} 45$ & 5 \\
ZJ & $\mathrm{H} 11, \mathrm{H} 12, \mathrm{H} 14, \mathrm{H} 17, \mathrm{H} 26, \mathrm{H} 27, \mathrm{H} 52$ & 5 \\
XH & $\mathrm{H} 10, \mathrm{H} 16, \mathrm{H} 24, \mathrm{H} 35, \mathrm{H} 51$ & 5 \\
QY & $\mathrm{H} 9, \mathrm{H} 15, \mathrm{H} 39, \mathrm{H} 53$ & 4 \\
LS & $\mathrm{H} 18, \mathrm{H} 25, \mathrm{H} 34, \mathrm{H} 38, \mathrm{H} 56$ & 5 \\
DW & $\mathrm{H} 21, \mathrm{H} 22, \mathrm{H} 33, \mathrm{H} 43, \mathrm{H} 46, \mathrm{H} 47, \mathrm{H} 49$ & 7 \\
RJF & $\mathrm{S}$ & 5 \\
\hline
\end{tabular}

Big Bone (DG), Haidong (HD), Taibai (TB), Silkie (SY), Tibet (ZJ), Xinghua (XH), Qingyuan (QY), Lingshan (LS), Dwarf White (DW), and Red Junglefowl (RJF).

\section{Genetic diversity analysis}

Haplotype diversity and nucleotide diversity of the chicken HSP70 gene that were determined in 10 breeds in this study were 0.9740 and 0.0016 , respectively, and the average number of nucleotide differences of all breeds was 4.1998 (Table 5). This revealed a high haplotype diversity of the HSP70 gene in the 10 breeds, which approached 1 in the Qiingyuan and Xinghua breeds. The variation in the nucleotide diversity and the average number of nucleotide differences among breeds were similar. However, the Silkie breed had the low- 
est haplotype diversity, nucleotide diversity, and average number of nucleotide differences, which were $0.7222,2.5000$, and 0.0010 , respectively, while Red Junglefowl had the highest nucleotide diversity and average number of nucleotide differences, which were 4.800 and 0.0018 , respectively.

Table 5. Haplotype diversity and nucleotide diversity of the $H S P 70$ gene in 10 chicken breeds.

\begin{tabular}{lccccc}
\hline Breed & Sample & Number of haplotypes & Haplotype diversity & Average number of nucleotide differences & Nucleotide diversity \\
\hline ZJ & 11 & 9 & 0.9636 & 3.6727 & 0.0014 \\
DG & 10 & 8 & 0.9330 & 3.4444 & 0.0013 \\
HD & 12 & 6 & 0.8030 & 3.0606 & 0.0012 \\
LS & 11 & 9 & 0.9636 & 4.6546 & 0.0018 \\
QY & 8 & 8 & 1.0000 & 4.3571 & 0.0017 \\
SY & 9 & 5 & 0.7222 & 2.5000 & 0.0010 \\
TB & 12 & 10 & 0.9545 & 3.7273 & 0.0014 \\
XH & 8 & 8 & 1.0000 & 4.4643 & 0.0017 \\
DW & 10 & 8 & 0.9556 & 4.1778 & 0.0016 \\
RJF & 11 & 10 & 0.9818 & 4.8000 & 0.0018 \\
Total & 102 & 57 & 0.9740 & 4.1998 & 0.0016 \\
\hline Big
\end{tabular}

Big Bone (DG), Haidong (HD), Taibai (TB), Silkie (SY), Tibet (ZJ), Xinghua (XH), Qingyuan (QY), Lingshan (LS), Dwarf White (DW), and Red Junglefowl (RJF).

\section{AMOVA}

AMOVA of the chicken $H S P 70$ gene in 10 breeds revealed that variance within breeds only accounted for $5.37 \%$ of the total variance in the chicken $H S P 70$ gene, but the variance between breeds accounted for $94.63 \%$ of the total variance; the fixation index value was 0.05372 $(\mathrm{P}<0.01$; Table 6). These results indicated that there was significant genetic differentiation of the chicken HSP70 gene between breeds. Further analysis of the genetic differentiation of the HSP70 gene between breeds was performed (Table 7), and the genetic differentiation of the HSP70 gene among breeds was significantly different.

Table 6. AMOVA of the HSP70 gene in 10 chicken breeds.

\begin{tabular}{lrcccc}
\hline Source of variation & d.f. & Sum of squares & Variance component & Percentage of variation $(\%)$ & Fixation index $\left(F_{\text {ST }}\right)$ \\
\hline Between breeds & 9 & 6.575 & 0.0263 & 5.37 & $0.0537^{* *}$ \\
Within breeds & 92 & 42.601 & 0.4630 & 94.63 & \\
Total & 101 & 49.176 & 0.4893 & & \\
\hline
\end{tabular}

d.f. $=$ degrees of freedom. $* *$ Denotes a highly significant difference $(\mathrm{P}<0.01)$.

Table 7. Fixation index $\left(F_{\mathrm{ST}}\right)$ values and the corresponding P values of the $H S P 70$ gene among 10 chicken breeds.

\begin{tabular}{|c|c|c|c|c|c|c|c|c|c|c|}
\hline & DG & HD & TB & SY & $\mathrm{ZJ}$ & $\mathrm{XH}$ & QM & LS & DW & RJF \\
\hline DG & & 0.0000 & 0.1982 & 0.0000 & 0.0270 & 0.3694 & 0.2072 & 0.1982 & 0.2522 & 0.0360 \\
\hline HD & $0.1113 * *$ & & 0.0360 & 0.0000 & 0.0180 & 0.0540 & 0.1441 & 0.0000 & 0.0180 & 0.0000 \\
\hline TB & 0.0233 & $0.0896^{*}$ & & 0.0090 & 0.1892 & 0.2342 & 0.8018 & 0.1802 & 0.5856 & 0.1622 \\
\hline SY & $0.1609 * *$ & $0.2350 * *$ & $0.1321 * *$ & & 0.0000 & 0.1261 & 0.0180 & 0.0180 & 0.0180 & 0.0270 \\
\hline ZJ & $0.0513^{*}$ & $0.0755^{*}$ & 0.0186 & $0.1528 * *$ & & 0.2522 & 0.4595 & 0.0450 & 0.0270 & 0.4234 \\
\hline $\mathrm{XH}$ & 0.0095 & 0.0752 & 0.0238 & 0.0774 & 0.0189 & & 0.9910 & 0.4595 & 0.4685 & 0.7297 \\
\hline QY & 0.0221 & 0.0545 & -0.0188 & $0.1298 *$ & 0.0076 & 0.0000 & & 0.7568 & 0.9910 & 0.4955 \\
\hline LS & 0.0248 & $0.1177 * *$ & 0.0186 & $0.0891 *$ & $0.0364 *$ & 0.0076 & -0.0158 & & 0.5676 & 0.3964 \\
\hline DW & 0.0264 & $0.1002 *$ & -0.0053 & $0.1399 *$ & $0.0404 *$ & 0.0105 & -0.0287 & -0.0150 & & 0.0721 \\
\hline RJF & $0.0422 *$ & $0.1087 * *$ & 0.0246 & $0.0985^{*}$ & 0.0109 & -0.0020 & 0.0094 & 0.0192 & 0.0312 & \\
\hline
\end{tabular}

$F_{\mathrm{ST}}$ values are shown below diagonal and $\mathrm{P}$ values are shown above diagonal. **Denotes highly significant differences $(\mathrm{PT}<0.01)$. *Denotes significant differences $(\mathrm{P}<0.05)$. Big Bone (DG), Haidong (HD), Taibai (TB), Silkie (SY), Tibet (ZJ), Xinghua (XH), Qingyuan (QY), Lingshan (LS), Dwarf White (DW), and Red Junglefowl (RJF). 


\section{DISCUSSION}

Phenotypic differences between species can be due to genetic changes that alter gene products as well as their expression level (Hoffmann and Willi, 2008; McManus et al., 2010). Mutations in gene sequences that change gene expression by altering the morphology and physiology have been reported (Chen et al., 2007; Graze et al., 2009). Chen et al. (2011) reported that changes in the AT content of the promoter markedly affect HSP70 expression of $H S P 70$, which may play an important role in regulatory evolution. Therefore, other changes in the chicken HSP70 gene sequence might also explain the evolution of this gene. In this study, 34 SNPs and 2 indel mutations in the chicken HSP70 gene were identified. Thirty SNPs were transitions and the other 4 were transversions. The transition incidence was 7.4 times higher than the transversion incidence. The high incidence of transitions may be due to the location of cytosine residues in the $\mathrm{CpG}$ dinucleotide and could be easily changed to thymine (Wang et al., 1998). The average density of SNPs in the chicken genome was reported to be 5:1000 (Wong et al., 2004). In this study, the average density of SNPs in the chicken HSP70 gene was 13.1:1000, indicating that the structural polymorphism of the $H S P 70$ gene was very rich. On the other hand, 24 SNPs in the coding region of the chicken HSP70 gene were located in the ATP enzyme active region, polypeptide combining region, and C-terminal region, and some SNPs changed the amino acid sequence. Theses SNPs may affect the binding of peptide substrates with $H S P 70$ or the activation of $H S P 70$ (Favatier et al., 1997).

Our calculated nucleotide diversity of the chicken HSP70 gene was lower than that of Berlin and Ellegren (2004). This conflicted with the high SNP density of the HSP70 gene (13.1 $\mathrm{SNPs} / \mathrm{kb}$ ). A possible reason for this was that nucleotide variation could only occur two times at each SNP site, so the SNP density was relatively higher than the nucleotide diversity. Fiftyseven haplotypes were identified in this study; of these, 14 were shared within and between breeds and 43 were breed-specific. In the native Chinese breeds, the highest haplotype diversity approached 1 (Qingyuan and Xinghua), and the lowest haplotype diversity was 0.7222 (Silkie). This indicated that the haplotypes of the HSP70 gene in native Chinese chickens were rich, and we believed that the rich diversity of SNPs was the direct reason for the high degree of haplotype diversity. AMOVA of the HSP70 gene also indicated that nucleotide mutations in the HSP70 gene were rich in native Chinese chickens. However, most of the variations were breed-specific. Therefore, we hypothesized that there was a clear genetic differentiation in the HSP70 gene between breeds and that the sequence of the chicken HSP70 gene that changed during the long history of evolution and natural and artificial selection may also play a role in this process.

Further analysis revealed that the genetic difference between Xinghua and other breeds was small; however, the genetic difference between Silkie and other breeds (except Xinghua) was large. Additionally, the nucleotide diversity and haplotype diversity were the lowest in the Silkie breed; this might be caused by sampling or was probably due to the inclusion of the Silkie breed in the long process of domestication and improvement, in which artificial selection can lead to beneficial allele fixation or flock expansion.

\section{CONCLUSIONS}

Our results demonstrate the abundant structural polymorphism of the chicken HSP70 gene. The underlying mechanism of this polymorphism may be due to natural and artificial selection. 


\section{ACKNOWLEDGMENTS}

Research supported by a grant from the National Natural Sciences Foundation of China (\#30972093) and the Key Technology Research and Development Program of Guangdong Emerging Strategic Industries (\#2012A020800005).

\section{Supplementary material}

\section{REFERENCES}

Berlin S and Ellegren H (2004). Chicken W: a genetically uniform chromosome in a highly variable genome. Proc. Natl. Acad. Sci. U. S. A. 101: 15967-15969.

Bromham L (2009). Why do species vary in their rate of molecular evolution? Biol. Lett. 5: 401-404.

Chen B, Walser JC, Rodgers TH, Sobota RS, et al. (2007). Abundant, diverse, and consequential P elements segregate in promoters of small heat-shock genes in Drosophila populations. J. Evol. Biol. 20: 2056-2066.

Chen B, Jia T, Ma R, Zhang B, et al. (2011). Evolution of $h s p 70$ gene expression: a role for changes in AT-richness within promoters. PLoS One 6: e20308.

Favatier F, Bornman L, Hightower LE, Günther E, et al. (1997). Variation in hsp gene expression and Hsp polymorphism: do they contribute to differential disease susceptibility and stress tolerance? Cell Stress Chaperones 2: 141-155.

Garbuz DG, Yushenova IA, Zatsepina OG, Przhiboro AA, et al. (2011). Organization and evolution of hsp70 clusters strikingly differ in two species of Stratiomyidae (Diptera) inhabiting thermally contrasting environments. BMC Evol. Biol. 11: 74 .

Graze RM, McIntyre LM, Main BJ, Wayne ML, et al. (2009). Regulatory divergence in Drosophila melanogaster and $D$. simulans, a genomewide analysis of allele-specific expression. Genetics 183: 547-561.

Guo R, Ebenezer V and Ki JS (2012). Transcriptional responses of heat shock protein 70 (Hsp70) to thermal, bisphenol A, and copper stresses in the dinoflagellate Prorocentrum minimum. Chemosphere 89: 512-520.

Hoffmann AA and Willi Y (2008). Detecting genetic responses to environmental change. Nat. Rev. Genet. 9: 421-432.

Janecka J, Chowdhary B and Murphy W (2012). Exploring the correlations between sequence evolution rate and phenotypic divergence across the Mammalian tree provides insights into adaptive evolution. J. Biosci. 37: 897-909.

Kregel KC (2002). Heat shock proteins: modifying factors in physiological stress responses and acquired thermotolerance. J. Appl. Physiol. 92: 2177-2186.

Mayer MP and Bukau B (2005). Hsp70 chaperones: cellular functions and molecular mechanism. Cell Mol. Life Sci. 62: 670-684.

McManus CJ, Coolon JD, Duff MO, Eipper-Mains J, et al. (2010). Regulatory divergence in Drosophila revealed by mRNA-seq. Genome Res. 20: 816-825.

Rozas J, Sánchez-DelBarrio JC, Messeguer X and Rozas R (2003). DnaSP, DNA polymorphism analyses by the coalescent and other methods. Bioinformatics 19: 2496-2497.

Tamura K, Dudley J, Nei M and Kumar S (2007). MEGA4: Molecular Evolutionary Genetics Analysis (MEGA) software version 4.0. Mol. Biol. Evol. 24: 1596-1599.

Wang DG, Fan JB, Siao CJ, Berno A, et al. (1998). Large-scale identification, mapping, and genotyping of singlenucleotide polymorphisms in the human genome. Science 280: 1077-1082.

Welch JJ and Bromham L (2005). Molecular dating when rates vary. Trends Ecol. Evol. 20: 320-327.

Wong GK, Liu B, Wang J, Zhang Y, et al. (2004). A genetic variation map for chicken with 2.8 million single-nucleotide polymorphisms. Nature 432: 717-722. 